\title{
Design and Evaluation of Robo-Advisors Using Index Fund and Alternative Assets of Cryptocurrency and Gold: Case of Indonesian Capital Market
}

\author{
Dhanar Prayoga ${ }^{1}$, Deddy P. Koesrindartoto, Ph.D. ${ }^{2}$ \\ ${ }^{1,2}$ School of Business and Management of Institut Teknologi Bandung, Bandung, Indonesia
}

\begin{abstract}
Robo-advisor is one of the most prominent innovation in the wealth management industry, and its success in Indonesia has been evident in the case of Bibit. Therefore, wealth management companies need to employ Robo-Advisor to overcome their competition. This research aims to give recommendation on asset allocation method and asset class selection for Robo-Advisors in Indonesia using Sharpe Ratio Analysis. Then, the author will analyze the robo-advisor's performance during equity market downturn. Finally, The Robo-Advisor's actual performance will be tested in 2018, 2019, and 2020. The Sharpe ratio analysis result showed that Robo-Advisors seeking higher risk-adjusted return should choose mean-variance optimization over risk parity for asset allocation method, and the inclusion of gold and bitcoin in a portfolio of stock mutual fund and bond mutual fund increases the risk-adjusted return of the portfolio. The proposed robo-advisor's portfolio protected investors from equity market downturn in 2011-2010 in 83,3\% of the case. Finally, the proposed robo-advisor's portfolio generated better return for the conservative, moderate and aggressive investor during 2018, 2019, and 2020 when compared to LQ45.
\end{abstract}

KEYWORDS: Cryptocurrency, Markowitz Portfolio Theory, Robo-Advisor, Risk Parity, Sharpe Ratio.

\section{INTRODUCTION}

According to KPMG's report (2021), the wealth management industry in Asia Pacific is going to experience a high level of growth caused by digital innovation within the industry. One of the most prominent innovation is Robo-advisor. Robo-advisors are attractive because it is lower in cost and does not make behavioral biases (such as trying to time the market) that can save investors up to $4,4 \%$ per year (Uhl \& Rohner, 2018). In Indonesia, the success of Robo-Advisor is evident in the case of Bibit, which were the most popular investment fintech platform in Indonesia (Katadata, 2020). Therefore, wealth management companies need to employ RoboAdvisor to be able to overcome the competition.

One of the problems in implementing a robo-advisor is asset allocation. Most robo-advisor in US uses mean-variance as a base for their portfolio optimization (Lam \& Swensen, 2016). On the other hand, risk parity is gaining popularity after 2008 and it produced a better risk-adjusted return than commonly used asset allocation in the world (Kurniawan \& Sumirat, 2020). Therefore, a research is needed to choose the appropriate asset allocation method for the robo-advisor.

Another problem that needs to be addressed is investment product selection. In Indonesia, Indonesian bonds tend to have comovement with stocks, and fails to act as a safe haven during market downturn (Siahaan \& Robiyanto, 2019). This makes Indonesian wealth manager faces threat from foreign wealth managers, which are attractive because of their global capabilities and their access to international market and products (KPMG, 2021), which may become a hedge especially during equity market drawdown. This problem might be solved by incorporating gold in the investment portfolio, which acts as a safe haven during equity market drawdown for investors in emerging countries such as Indonesia (Gürgün \& Ünalmis, 2014); and by incorporating cryptocurrency that has high return and can increase the Sharpe ratio of a portfolio (Hougan \& Lawant, 2021).

\section{LITERATURE REVIEW}

\section{Robo-Advisor}

Robo-advisor is an algorithm that helps investor manage their investment. According to Lam (2016), Robo-advisors performs three main jobs: Asset allocation, implementation, and portfolio monitoring and rebalancing. Asset allocation determines the weightings of each asset classes within the portfolio. Implementation helps investor chooses the appropriate investment products to represent each asset classes. Finally, portfolio monitoring and rebalancing performs rebalancing when needed, to ensure that investors achieves their investment goal. 


\section{International Journal of Current Science Research and Review}

ISSN: 2581-8341

Volume 05 Issue 02 February 2022

DOI: 10.47191/ijesrr/V5-i2-12, Impact Factor: 5.825

IJCSRR@ 2022

www.ijjesrr.org

\section{Index Fund}

An index fund tries to match the performance of a broad market index (Bodie, Kane, \& Marcus, 2018). Index fund is passively managed passively tracks an index and does not trying to beat the market, unlike actively managed mutual fund that tries to beat the market by actively selecting securities.

There are several advantages for choosing index fund. The first reason is cost, because the Total Expense Ratio of index fund are lower (Uhl \& Rohner, 2018). Another reason to choose index fund is performance,to S\&P Global (2021), the majority of US actively managed mutual fund underperforms the benchmark. The same result is found in Indonesia, of which 94\% of actively managed stock mutual fund and $95 \%$ of passively managed bond mutual funds underperforms the benchmark (Kurniawan \& Sumirat, 2020).

\section{Risk Parity}

A risk parity portfolio is an equally weighted portfolio, where the weights refer to marginal risk contribution rather than dollar amount invested in each asset (Hossein Kazemi, 2012). According to Kazemi (2012), the marginal risk contribution are:

$$
\begin{aligned}
& M C_{1}=w_{1} \times \frac{\Delta \text { in } \sigma\left[R_{p}\right]}{\Delta \text { in } w_{1}}=w_{1} \times\left(\frac{w_{1} \sigma\left[R_{1}\right]^{2}+w_{2} \operatorname{Cov}\left[R_{1}, R_{2}\right]}{\sigma\left[R_{p}\right]}\right) \\
& M C_{2}=w_{1} \times \frac{\Delta \text { in } \sigma\left[R_{p}\right]}{\Delta \text { in } w_{2}}=w_{2} \times\left(\frac{w_{2} \sigma\left[R_{2}\right]^{2}+w_{1} \operatorname{Cov}\left[R_{1}, R_{2}\right]}{\sigma\left[R_{p}\right]}\right)
\end{aligned}
$$

The rate of return and standard deviation of the rate of return on this portfolio, $\mathrm{E}[\mathrm{Rv}]$ and $\sigma\left[\mathrm{R}_{\mathrm{p}}\right]$ are:

$$
\begin{aligned}
& E\left[R_{p}\right]=w_{1} E\left[R_{1}\right]+w_{2} E\left[R_{2}\right] \\
& \sigma\left[R_{p}\right]=\sqrt{w_{1}^{2} \sigma\left[R_{1}\right]^{2}+w_{2}^{2} \sigma\left[R_{2}\right]^{2}+2 w_{1} w_{2} \operatorname{Cov}\left[R_{1}, R_{2}\right]}
\end{aligned}
$$

\section{METHODOLOGY}

\section{Data Collection}

The data are using the monthly price data from January 2011 - December 2020. The mutual fund's NAV data are taken from pasardana.id. The price of Bitcoin and Gold are taken from investing.com using BTCUSD and XAUIDR, respectively, and then multiplied by USDIDR. The risk-free rate used in this research is the BI's deposit facility rate of $2,75 \%$.

\section{Data Processing and Analysis}

The first step of this research is to choose an investment product to represent each asset classes. The investment product's index needs to be exist since January 2011. Then, the author will build an investment portfolio using risk parity and mean-variance optimization using four asset classes of stock and bond mutual funds, and gold and bitcoin. Then, the author will build a portfolio using only mutual funds another portfolio that incorporates gold and bitcoin.

The next step is to perform Sharpe ratio analysis to determine which asset classes and asset allocation method provides a better risk adjusted performance. Then, selected portfolio's monthly return would be compared with IDX Composite to analyze the roboadvisor's performance during equity market drawdown. Finally, the robo-advisor's portfolio actual performance in 2018, 2019, and 2020 will be compared with LQ45 to analyze its actual performance.

The portfolios in this research will be using annual rebalancing every January $1^{\text {st }}$. annual rebalancing is chosen because Investors would be well-served if they implemented disciplined calendar-based rebalancing (CFA Montreal, 2016). In addition, this research will use 3 risk profile: conservative, moderate, and aggressive. The moderate portfolio will use the recommended portfolio, while the conservative and aggressive will use portfolio with standard deviation of around 5\% lower and higher than the recommended portfolio. This is because Betterment, a prominent robo-advisor in U.S. uses portfolio 3\%-7\% below and higher than its recommended portfolio for their appropriately conservative and aggressive portfolio (Betterment, 2014), and 5\% is the median of $3 \%-7 \%$. 


\section{International Journal of Current Science Research and Review}

ISSN: 2581-8341

Volume 05 Issue 02 February 2022

DOI: 10.47191/ijesrr/V5-i2-12, Impact Factor: 5.825

IJCSRR@ 2022

Www.ijcsrr.org

\section{FINDINGS AND ARGUMENT}

The investment product used in this research are LQ45 to represent stock mutual fund, Bahana ABF Indonesia Bond Fund (ABFI) to represent bond mutual fund. Gold are used to represent gold, and Bitcoin is used to represent cryptocurrency. LQ45 is chos en because it consisted by the highest number of stock which was 45, compared to 25, 30, and 27 of Sri-Kehati, Jakarta Islamic Index, and Bisnis-27 respectively, that satisfies the methodology requirement. Then, the selected investment product is used to create portfolio as illustrated in Table 1.

Table 1. Portfolios Generated using Mean-Variance (Above) and Risk Parity (Below)

\begin{tabular}{|c|c|c|c|c|c|c|c|c|c|}
\hline \multirow[b]{2}{*}{ No. } & \multirow{2}{*}{$\begin{array}{l}\text { Portfolio } \\
\text { Standard } \\
\text { Deviation }\end{array}$} & \multirow[b]{2}{*}{$\begin{array}{l}\text { Portfolio } \\
\text { Return }\end{array}$} & \multicolumn{5}{|c|}{ Portfolio Asset Allocation } & \multirow[b]{2}{*}{ Note } & \multirow{2}{*}{$\begin{array}{l}\text { LQ45 } \\
\text { (Benchmark) } \\
\text { Sharpe Ratio }\end{array}$} \\
\hline & & & $\begin{array}{l}\text { LQ45 } \\
\text { Weight }\end{array}$ & $\begin{array}{l}\text { ABFI } \\
\text { Weight }\end{array}$ & $\begin{array}{l}\text { Gold } \\
\text { Weight }\end{array}$ & $\begin{array}{l}\text { Bitcoin } \\
\text { Weight }\end{array}$ & $\begin{array}{l}\text { Sharpe } \\
\text { Ratio }\end{array}$ & & \\
\hline 1 & $7,51 \%$ & $9,72 \%$ & $0,00 \%$ & $80,06 \%$ & $19,27 \%$ & $0,67 \%$ & $92,80 \%$ & & \\
\hline 2 & $8,00 \%$ & $12,53 \%$ & $0,00 \%$ & $81,18 \%$ & $16,88 \%$ & $1,94 \%$ & $\begin{array}{l}122,25 \\
\%\end{array}$ & & \\
\hline 3 & $9,00 \%$ & $14,78 \%$ & $0,00 \%$ & $82,10 \%$ & $14,95 \%$ & $2,95 \%$ & $\begin{array}{l}133,66 \\
\%\end{array}$ & & \\
\hline 4 & $10,00 \%$ & $16,46 \%$ & $0,00 \%$ & $82,79 \%$ & $13,51 \%$ & $3,70 \%$ & $\begin{array}{l}137,07 \\
\%\end{array}$ & & \\
\hline 5 & $11,00 \%$ & $17,92 \%$ & $0,00 \%$ & $83,36 \%$ & $12,28 \%$ & $4,36 \%$ & $\begin{array}{l}137,92 \\
\%\end{array}$ & & \\
\hline 6 & $11,17 \%$ & $18,15 \%$ & $0,00 \%$ & $83,47 \%$ & $12,07 \%$ & $4,46 \%$ & $137,93 \%$ & \begin{tabular}{|l|} 
Best \\
Sharpe
\end{tabular} & $4,94 \%$ \\
\hline 7 & $12,00 \%$ & $19,27 \%$ & $0,00 \%$ & $83,91 \%$ & $11,13 \%$ & $4,96 \%$ & $\begin{array}{l}137,67 \\
\%\end{array}$ & & \\
\hline 8 & $13,00 \%$ & $20,55 \%$ & $0,00 \%$ & $84,43 \%$ & $10,03 \%$ & $5,54 \%$ & $\begin{array}{l}136,91 \\
\%\end{array}$ & & \\
\hline 9 & $14,00 \%$ & $21,78 \%$ & $0,00 \%$ & $84,95 \%$ & $8,96 \%$ & $6,09 \%$ & $\begin{array}{l}135,90 \\
\%\end{array}$ & & \\
\hline 10 & $15,00 \%$ & $22,97 \%$ & $0,00 \%$ & $85,34 \%$ & $8,03 \%$ & $6,63 \%$ & $\begin{array}{l}134,80 \\
\%\end{array}$ & & \\
\hline 11 & $16,00 \%$ & $24,14 \%$ & $0,00 \%$ & $85,90 \%$ & $6,95 \%$ & $7,15 \%$ & $133,67 \%$ & & \\
\hline
\end{tabular}

Investment Asset

Classes

\begin{tabular}{|l|l|l|l|l|}
\cline { 2 - 5 } & LQ45 & ABFI & Gold & Bitcoin \\
\hline $\begin{array}{l}\text { Expected Asset } \\
\text { Return }\end{array}$ & $3,59 \%$ & $8,38 \%$ & $7,60 \%$ & $229,41 \%$ \\
\hline Standard Deviation & $16,99 \%$ & $8,49 \%$ & $16,40 \%$ & $217,61 \%$ \\
\hline Asset Weight & $22,41 \%$ & $46,56 \%$ & $28,75 \%$ & $2,28 \%$ \\
\hline $\begin{array}{l}\text { Marginal } \\
\text { Contribution (MC) }\end{array}$ & $2,32 \%$ & $2,32 \%$ & $2,32 \%$ & $2,32 \%$ \\
\hline Portfolio Risk & \multicolumn{3}{|c|}{$12,13 \%$} \\
\hline Portfolio Return & $9,27 \%$ & \\
\hline Sharpe Ratio & \multicolumn{5}{|c|}{$101,23 \%$} \\
\hline
\end{tabular}




\section{International Journal of Current Science Research and Review}

ISSN: 2581-8341

\section{Volume 05 Issue 02 February 2022}

DOI: 10.47191/ijesrr/V5-i2-12, Impact Factor: 5.825

IJCSRR@ 2022

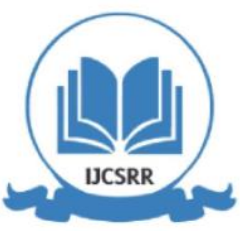

www.ijcsrr.org

The next step is performing Sharpe Ratio Analysis to choose the appropriate asset allocation method and asset classes selection. Table 2 illustrates the Sharpe Ratio comparison of the portfolios. As we can see, the mean-variance optimization portfolio has a better Sharpe Ratio compared to risk parity portfolio, and the inclusion of gold and bitcoin increases the risk-adjusted return of the portfolio. In addition, all portfolio posted a better risk-adjusted return than LQ45. Therefore, the robo-advisor will use four asset classes and mean-variance optimization.

Table 2. Performance Comparison of different Asset Allocation Method (above) and Asset Class Selection (below)

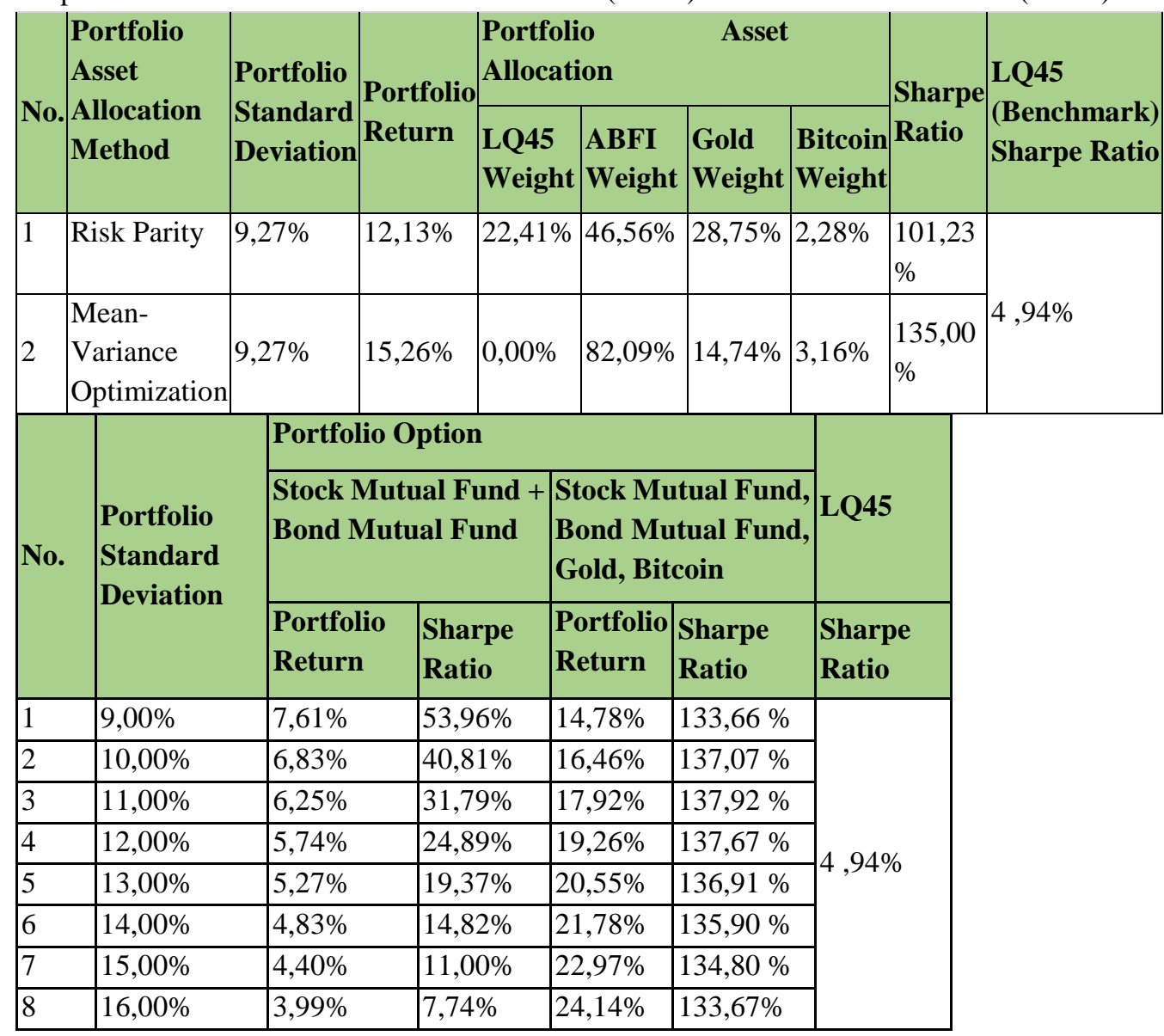

The back-testing of the portfolio showed that the proposed robo-advisor's portfolio offered protection during equity market drawdown in $83.3 \%$ of the case. During 2011-2020, IDX Composite experienced 42 months of negative return. Out of those numbers, the robo-advisor's portfolio produced better return than IDX Composite for 35 months, and worse in 7 monhts. Therefore the proposed robo-advisor's portfolio can protect investor during equity market drawdown.

Table 3 illustrates the portfolio actual performance in 2018, 2019, and 2020. For testing in 2018, the portfolio is created using data from 2011-2017. In 2018, 2019, and 2020, the proposed robo-advisor for all risk profiles generated a better return for investors. Using Sharpe ratio analysis, the proposed portfolio performed better in 2019 and 2020, but performed worse during 2018 . The result in 2018 is caused by the extreme volatility in cryptocurrency market, at which returned $-71,62 \%$ for the year. However, all portfolios only experienced a single digit negative return. This shows how the portfolio manages the extreme volatility in cryptocurrency market. 


\section{International Journal of Current Science Research and Review}

ISSN: 2581-8341

Volume 05 Issue 02 February 2022

DOI: 10.47191/ijesrr/V5-i2-12, Impact Factor: 5.825

IJCSRR@ 2022

WWW.ijesrr.org

Table 3. Actual Performance of Proposed Robo-Advisor in 2018, 2019, and 2020

\begin{tabular}{|c|c|c|c|c|c|c|c|c|c|}
\hline Year & \multicolumn{3}{|c|}{2018} & \multicolumn{3}{|c|}{2019} & \multicolumn{3}{|c|}{2020} \\
\hline Risk Profile & Conservative & Moderate & Aggressive & Conservative & Moderate & Aggressive & Conservative & Moderate & Aggressive \\
\hline bservation & \multirow{2}{*}{\multicolumn{3}{|c|}{$\begin{array}{l}2011 \\
2017\end{array}$}} & \multirow{2}{*}{\multicolumn{3}{|c|}{$\begin{array}{l}2011 \\
2018 \\
\end{array}$}} & \multirow{2}{*}{\multicolumn{3}{|c|}{$\begin{array}{l}2011 \\
2019\end{array}$}} \\
\hline Period & & & & & & & & & \\
\hline $\begin{array}{l}\text { LQ45 } \\
\text { Weight }\end{array}$ & $0,00 \%$ & $0,00 \%$ & $0,00 \%$ & $0,00 \%$ & $0,00 \%$ & $0,00 \%$ & $0,00 \%$ & $0,00 \%$ & $0,00 \%$ \\
\hline $\begin{array}{l}\text { ABFI } \\
\text { Weight }\end{array}$ & $88,64 \%$ & $93,65 \%$ & $91,59 \%$ & $93,37 \%$ & $91,47 \%$ & $89,42 \%$ & $85,03 \%$ & $93,97 \%$ & $91,68 \%$ \\
\hline Gold Weight & $7,74 \%$ & $0,00 \%$ & $0,00 \%$ & $0,68 \%$ & $0,00 \%$ & $0,00 \%$ & $12,21 \%$ & $0,00 \%$ & $0,00 \%$ \\
\hline $\begin{array}{l}\text { Bitcoin } \\
\text { Weight } \\
\end{array}$ & $3,62 \%$ & $6,35 \%$ & $8,41 \%$ & $5,95 \%$ & $8,53 \%$ & $10,58 \%$ & $2,76 \%$ & $6,03 \%$ & $8,32 \%$ \\
\hline $\begin{array}{l}\text { Risk-Free } \\
\text { Rate }\end{array}$ & \multicolumn{3}{|c|}{$3,50 \%$} & \multicolumn{3}{|c|}{$5,25 \%$} & \multicolumn{3}{|c|}{$4,25 \%$} \\
\hline \begin{tabular}{l|} 
LQ45 \\
(Benchmark) \\
Return \\
\end{tabular} & \multicolumn{3}{|c|}{$-8,96 \%$} & \multicolumn{3}{|c|}{$3,23 \%$} & \multicolumn{3}{|c|}{$-7,24 \%$} \\
\hline $\begin{array}{l}\text { Realized } \\
\text { Return } \\
\end{array}$ & $-4,32 \%$ & $-6,73 \%$ & $-8,16 \%$ & $17,62 \%$ & $19,53 \%$ & $21,05 \%$ & $23,58 \%$ & $31,63 \%$ & $38,34 \%$ \\
\hline \begin{tabular}{l|} 
LQ45 \\
Benchmark) \\
Standard \\
Deviation \\
\end{tabular} & \multicolumn{3}{|c|}{$13,27 \%$} & \multicolumn{3}{|c|}{$11,84 \%$} & \multicolumn{3}{|c|}{$32,58 \%$} \\
\hline $\begin{array}{l}\text { Realized } \\
\text { Standard } \\
\text { Deviation }\end{array}$ & $5,14 \%$ & $5,80 \%$ & $5,86 \%$ & $8,78 \%$ & $11,29 \%$ & $13,33 \%$ & $7,98 \%$ & $12,37 \%$ & $14,53 \%$ \\
\hline \begin{tabular}{l|} 
LQ45 \\
(Benchmark) \\
Sharpe Ratio
\end{tabular} & \multicolumn{3}{|c|}{$-93,88 \%$} & \multicolumn{3}{|c|}{$-17,07 \%$} & \multicolumn{3}{|c|}{$-35,26 \%$} \\
\hline $\begin{array}{l}\text { Realized } \\
\text { Sharpe Ratio }\end{array}$ & $-152,14 \%$ & $-176,38 \%$ & $-198,98 \%$ & $140,89 \%$ & $126,48 \%$ & $118,53 \%$ & $242,23 \%$ & $221,34 \%$ & $234,62 \%$ \\
\hline
\end{tabular}

\section{CONCLUSIONS}

The Sharpe Ratio analysis shows that for robo-advisors seeking a better risk-adjusted return, mean-variance optimization should be used as the asset allocation method, and gold and bitcoin should be incorporated to the investment portfolio. In addition, the monthly return analysis showed that the proposed portfolio offered protection during equity market drawdown, of which it protected investors in 83,3\% of the case from months which IDX Composite returned negative in 2011-2020. Finally, the proposed portfolio generated better return than LQ45 in 2018, 2019, and 2020. The Sharpe ratio of the portfolio is better than LQ45 in 2020 and 2019, but worse than LQ45 in 2018. This is caused by the extreme volatility in cryptocurrency market in 2018, of which bitcoin returned $-71,62 \%$. This shows how the portfolio performs during extreme volatility in cryptocurrency market.

This study implies that by offering robo-advisors that employs four asset classes, wealth management companies in Indonesia can have a competitive advantage over mutual fund selling agency (APERD) that only sells mutual funds. In addition, Indonesian wealth management companies can protect investors during equity market drawdown, and hence can compete with foreign wealth management companies whose competitive advantage is access to international market and products, which may offer protection during equity market drawdown - a thing that Indonesian bonds has failed to offer.

Despite the results, further research should be considered to manage the limitations of this study. The first limitation is that this study used mean-variance without any constraints, which resulted in $0 \%$ weight in stock mutual funds in all portfolios. Several 


\section{International Journal of Current Science Research and Review}

ISSN: 2581-8341

Volume 05 Issue 02 February 2022

DOI: 10.47191/ijesrr/V5-i2-12, Impact Factor: 5.825

IJCSRR@ 2022

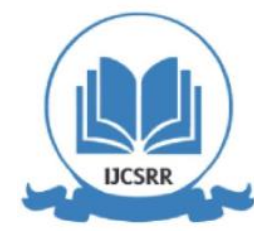

www.ijjcsrr.org

options such as adding constraints, using a variant of mean-variance, or other methods could be explored to ensure that the roboadvisor also recommended stock mutual fund. In addition, this study does not incorporate investor's investment goal into the model, and only focuses on generating the best risk-adjusted return. Therefore, further research that studies goal-based investing is a good opportunity to pursue.

\section{REFERENCES}

1. Betterment. (2014, August 19). Allocation Advice for Betterment Portfolios. Retreived from Betterment:

2. https://www.betterment.com/resources/stock-allocation-advice

3. Bodie, Z., Kane, A., \& Marcus, A. J. (2018). Investments, 11th Edition. New York: McGraw-Hill Education.

4. CFA Montreal. (2016). 3F: How To Rebalance. Dalam Investment Principles. Montreal: CFA Montreal.

5. Gürgün, G., \& Ünalmis, I. (2014). Is gold a safe haven against equity market investment in emerging and developing countries? Finance Research Letters, 11(4), 341-348.

6. Hossein Kazemi, P. (2012). An Introduction to Risk Parity. Alternative Investments Analyst Review, pp. 20-31.

7. Hougan, M., \& Lawant, D. (2021). Cryptoassets: The Guide to Bitcoin, Blockchain, and Cryptocurrencies for Investment Professionals. CFA Institute Research Foundation.

8. Katadata. (2020). Bibit, Fintech Investasi Paling Diminati Masyarakat. Retreived from https://databoks.katadata.co.id/datapublish/2020/12/23/bibit-fintech-investasi-paling-diminati-masyarakat

9. KPMG. (2021). Digital Wealth Management in Asia Pacific. Retreived from https://assets.kpmg/content/dam/kpmg/cn/pdf/en/2021/03/digital-wealth-management-in-asia-pacific.pdf

10. Kurniawan, W., \& Sumirat, E. (2020). Evaluation of Risk Parity Asset Allocation Strategy in Indonesia Mutual Fund During 2010-2019 Period. European Journal of Business and Management Research, 5(5).

11. Lam, J. W., \& Swensen, D. F. (2016). Robo-Advisors: A Portfolio Management Perspective. Yale College.

12. S\&P Global. (2021, March 11). SPIVA U.S. Scorecard 2020. Retreived from https://www.spglobal.com/spdji/en/documents/spiva/spiva-us-year-end-2020.pdf

13. Siahaan, G., \& Robiyanto. (2019). BOND AS A SAFE HAVEN DURING MARKET CRASH: EXAMINATION OF COVID-19 PANDEMIC IN ASEAN-5 . Jurnal Manajemen dan Kewirausahaan, 23(1), 1-9.

14. Uhl, W. M., \& Rohner, P. (2018). Robo-Advisors versus Traditional Investment Advisors: An Unequal Game. The Journal of Wealth Management, 21(1), 44-50.

Cite this Article: Dhanar Prayoga, Deddy P. Koesrindartoto, Ph.D. (2022). Design and Evaluation of Robo-Advisors Using Index Fund and Alternative Assets of Cryptocurrency and Gold: Case of Indonesian Capital Market. International Journal of Current Science Research and Review, 5(2), 390-395 